Ерохина Ю.В. Цветовое конструирование действительности в романе Аостоевского «Преступление и наказание» : семантика бледного цвета // Философия. ЖКурнал Высшей школы экономики. - 2021. - Т. 5, № 3. - С. 140-158.

\title{
ЦВЕТОВОЕ КОНСТРУИРОВАНИЕ
}

\section{АЕЙСТВИТЕЛЬНОСТИ В РОМАНЕ АОСТОЕВСКОГО «ПРЕСТУПЛЕНИЕ И НАКАЗАНИЕ ${ }^{* *}$}

\author{
СЕМАНТИКА БЛЕАНОГО ЦВЕТА
}

Получено: 15.07.2021. Рецензировано: 30.07.2021. Принято: 13.08.2021.

Аннотация: В статье предпринята попытка смоделировать образ того, что могло быть миром бледного цвета в романе Ф. М. Аостоевского «Преступление и наказание», включая все составляющие: лексику, название и значение цвета, коды, которые лежат в основе (культурные, государственно-правовые, социальные и пр.), нормативные правовые акты того времени, государственно-правовые идеи. Внимание в статье уделяется бледному цвету: определяется его герменевтическое поле, выявляются первичный (буквальный) и вторичный (иносказательный) смыслы. Ключом декодирования цветового кода в романе Ф. М. Аостоевского «Преступление и наказание» выступает трактат И. В. Гете «Учение о цвете. Теория познания», в частности, прослеживается взаимосвязь бледного цвета с желтым и синим/голубым цветами, дается их интерпретация, отмечается слабая интенсивность синего / голубого и особенная насыщенность желтого. Аелается вывод о возможности рассматривать бледный цвет в качестве знака при анализе отдельных сцен в романе. Обозначаются методологические и гносеологические трудности при декодировании и интерпретации бледного цвета в лексико-семантическом поле романа. Обращается внимание на необходимость изучения и реконструкции исторических условий создания литературного произведения для определения особенностей конституирования его смысла, для релевантного восприятия и интерпретации бледного цвета.

Ключевые слова: бледный цвет, Ф.М. Аостоевский, цветовой код, герменевтическое поле, государственно-правовые реформы, аристократия, интеллигенция, семантика.

DOI: $10.17323 / 2587-8719-2021-3-140-158$.

Цвет - сложная культурная конструкция, обсуждаемая как семиотический ресурс-способ, который, как и другие способы, многофункционален в использовании при создании знаков, локализованных в культуре.

*Ерохина Юлия Владимировна, к. ю. н., доцент, Национальный исследовательский университет «Высшая школа экономики» (Москва), yerohina@hse.ru, yulia-erohina@ yandex.ru, ORCID: 0000-0001-7004-4808.

** (C) Ерохина, Ю.В. (C) Философия. Журнал Высшей школы экономики.

Благодарности: статья подготовлена в рамках проекта «Право и искусство», реализуемого на факультете права Национального исследовательского университета «Высшая школа экономики». 
Оставив за рамками настоящей статьи философскую дискуссию о проблеме представления цветов, а также об отношениях между представлением цветов и их онтологической конструкцией и следуя за мыслью К. Л. Хардина о том, что цвета являются ментальными особенностями (Hardin, 1988), рассмотрим цветовой код в романе Ф. М. Достоевского «Преступление и наказание».

Цветовой код в романе возможно представить в виде некоей абстрактной конструкции (модели), состоящей из частей: желтый (золотой), бледный, белый (серебряный), синий / голубой, зеленый, красный, черный цвета,- которые имеют герменевтические поля, включающие первичный (буквальный) и вторичный (иносказательный) смыслы (Рикёр, Вдовина, 2008; Ricoeur, 1976). В рамках проводимых нами ранее исследований цветового кода романа были проанализированы желтый, белый и черный цвета, также обозначены методологические проблемы и логика исследования цветового кода в произведениях (Erokhina, 2021a, Erokhina, 2021b). В то же время стоит отметить, что при исследовании цветового кода в романе Ф. М. Достоевского «Преступление и наказание» возникают методологические и гносеологические трудности.

Методологические трудности связаны с тем, что цвета довольно сложно подвергнуть любой попытке обобщения, кроме анализа. Через синтез семиотического, исторического, правового, художественного и литературного анализа возможно выявить семантику бледного цвета в романе Достоевского. Гносеологические трудности обусловлены тем, что мы не можем применять к изображениям, памятникам и предметам, созданным в прошлые века, наши современные определения, концепции и классификации цвета. У общества прошлого эти критерии были иными, а у будущих обществ появятся новые (Пастуро, Кулиш, 2017). В любую эпоху зрительное восприятие-это феномен культуры. Причем длительное время картина мира воспринималась обществом как черно-белая «на фоне мерцающего черно-белого телевизора» (Джармен, Андронов, 2017: 17) и отсутствия цветной фотографии. Черно-белые изображения, экранизация сюжета романа в черно-белом фильме ${ }^{1}$ вполне могли сместить акценты в восприятии идеи романа «Преступление и наказание» в сторону психологического (эмоционального) способа. Как известно, белый и черный относятся к ахроматическим цветам и составляют разные

${ }^{1}$ «Преступление и наказание»-художественный фильм, снятый в 1969 г. режиссёром Львом Кулиджановым. 
полюса цветовосприятия. Сюда можно добавить белые страницы и черный цвет шрифта книг. Именно поэтому идет только восприятие некоей основы, исключающей многие существенные акценты, которые вносит цвет. По данной причине цветовой код в романе «Преступление и наказание» практически не исследован. Есть лишь единичные публикации, но и они имеют недостатки в исследовательской позиции авторов.

Обратимся к работам исследователей, которые изучали цветовую символику в произведениях Ф.М. Достоевского. Мысль о том, что Ф. М. Достоевский не является колористом, многократно повторялась и прочно укоренилась в научных исследованиях цветовой символики в литературном наследии писателя. В. Ф. Переверзев отмечает, что

бедность природы и бедность красок... вот, стало быть, те свойства, которыми характеризуется жизнь, развертывающаяся в произведениях Достоевского (Переверзев, 1912: $\left.73^{-} 74\right)$.

В итоге Переверзев приходит к заключению, что «его стиль беден красками» (там же: 6o, 69, 73-74). В. Ф. Боцяновский также считает, что

одной из характерных черт Достоевского является его нелюбовь к цвету и краске, как бы нарочитое пренебрежение к живописи. В произведениях Достоевского почти полное отсутствие живописи, цветов, пейзажа... То же наблюдается и в его портретах... (Боцяновский, 1921)

О. Н. Каленкова как бы между прочим отмечает, что Ф. М. Достоевский не принадлежит к писателям-колористам, «недаром „Петербург Достоевского“ вошел в мировую литературу как „серый город“» (Каленкова, 1982: 9). А.Л. Кушхова придерживается такого же мнения (Кушхова, 2011: 23-27). Общим в критических замечаниях является следующее: исследователи ставят в укор Ф. М. Достоевскому, что он не уделяет должного внимания реальному и объективному воспроизведению предметов и объектов окружающего мира с сохранением типичных черт и особенностей так, чтобы читателю все было понятно. В этом случае, по их мнению, не пришлось бы ничего домысливать. И здесь наблюдается приверженность критиков художественному реализму. Как отмечает Переверзев, для художников пушкинского направления характерен неторопливый, строго последовательный стиль изложения, доведенной до высокой степени способности рисовать портреты, пейзажи, формы (Переверзев, 1912: 62). У Достоевского же редко встретишь картины природы, а те, что встречаются, лишены красок, яркости и силы, у него нет портретов и описаний, он мало занимается формами 
(Переверзев, 1912: 74). И это объясняется иными художественными задачами, которые решает в своих произведениях Достоевский. На наш взгляд, особенность цветопередачи Достоевским заключается в том, что он кодирует информацию цветом с помощью слова. «Реальность Достоевского носит ярко выраженный семиотический характер»,-- отмечает С. М. Климова (Климова, 2018: 76). Можно провести аналогию метода Достоевского с художественным приемом, когда художники на холстах не изображали предметы материального мира, а передавали свою творческую идею с помощью слов, обращались не к физическим объектам, а к объектам, существующим в воображении, к понятиям.

Вопреки традиционному мнению о пренебрежительном отношении Ф. М. Достоевского к цветовому и красочному изображению явлений внешнего мира, С. М. Соловьев считает, что колорит Ф. М. Достоевского соответствует интенсивной духовной жизни его героев (Соловьев, 1979: 231). «Одна из особенностей изобразительности Достоевского - в чрезвычайно обширном, многозначном, многосмысловом использовании цвета»,- пишет С. М. Соловьев (там же). Эта особенность и определила повышенную важность многих цветов в произведениях Достоевского. Эмоциональное значение цвета в романе Достоевского «Преступление и наказание» изучено достаточно подробно, а смысловому значению цвета уделяется крайне мало внимания (Кравченко, 2019).

Трудности умножаются, когда анализу подвергаются попытки систематического объяснения значений цвета в романе «Преступление и наказание». Основным способом толкования цвета в произведении является психологический. Это в значительной степени сужает символическое значение цветового кода романа. В то же время надо обратить внимание на то, что интерпретация цветовых значений довольно затруднительна и связана с личными ассоциациями интерпретаторов. Проблема значения цвета может быть связана не с цветом или цветовыми терминами, а с нашими представлениями о значении или в данном случае с грамматикой (Kress, 2002: 343-344). И. В. Кочетова считает, что категория цвета используется в художественных текстах как средство, во-первых, эстетического и эмоционального воздействия на читателя и, во-вторых, выражения авторской интенции. Цветовое решение, к которому прибегает автор, влияет на образное мышление читателя и вызывает широкий круг ассоциаций (Кочетова, 2010: 103-107). Цветовые коды в литературном произведении способствуют конструированию новой действительности в воображении читателя. Для интерпретаторов в зависимости от их культурной принадлежности, образования 
и других факторов, влияющих на интерпретацию, могут раскрываться разные смыслы и грани романа. Следовательно, существенное для одного может быть несущественным для другого, все зависит от взгляда интерпретатора.

Вариативность интерпретации ставит обоснованный вопрос об объективности знания, получаемого с ее помощью. В целях устранения недостатков такой интерпретации в исследовании целесообразно обратиться к записным книжкам и тетрадям Достоевского. В них отражена работа автора над воплощением художественных и публицистических замыслов, наглядно представлен сложный творческий процесс писателя. Это важно для общей характеристики его духовных интересов начала и середины 1860-х гг. и выявления возможных смыслов цветового кода романа. Своеобразие записных книжек и тетрадей Ф. М. Достоевского заключается в разносторонности их содержания: они представляют собой и собственно записные книжки, и дневники, но в первую очередь творческие рукописи. Часто Ф. М. Достоевский пользовался двумя или даже тремя тетрадями одновременно, причем одна тетрадь могла заполняться в течение нескольких лет и, естественно, что в нее попадали записи, сделанные в разное время и на разные темы. Так, в тетрадях с черновиками к роману «Преступление и наказание» находятся полемические записи к статьям против журнала «Современник», редакторские заметки по журналу «Эпоха» и другие наброски, сделанные в 1864 г., когда не существовало даже замысла романа о Раскольникове (Зильберштейн, Розенблюм, 1971: 6).

Текст романа представляет собой «упакованную» коммуникацию, включающую не только все элементы цветового кода, но и сигналы для его декодирования. Для декодирования цветового кода романа «Преступление и наказание» обратимся к идеям И. В. Гете, изложенным в его трактате «Учение о цвете. Теория познания» (Гете, Лихтенштадт, 2012). Однако прежде следует остановиться на нескольких важных моментах. Критическое отношение к возможности сближения творчества Ф. М. Достоевского и И. В. Гете всегда присутствовало в достоевсковедении. Признавая бесспорное влияние $\Phi$. Шиллера на $\Phi$. М. Достоевского, исследователи, отчасти исходя из традиционного противопоставления Шиллера и Гете, часто не считали правомерным говорить о существенном гетевском влиянии. Несмотря на распространенность ныне существующих концепций, согласно которым Гете и Достоевский подчас предстают полными антиподами (Matl, 1932), не подлежит сомнению факт многочисленных со стороны Достоевского прямых и косвенных упоминаний 
Гете (Masaryk, 1932), цитирования его произведений и в разной степени опосредованного воздействия творчества Гете на него (Бахтин, 1979, Бахтин, 1986: 216-250). Исходным пунктом работы является тот признанный сегодня учеными факт, что обращения Ф. М. Достоевского к гетевским мотивам и образам обусловливаются пересечениями философских систем русского и немецкого писателей (Doblin, 1963: 312-321).

Гетевский контекст позволяет высветить новые грани творчества Достоевского. Подчеркну общеизвестный факт исключительности значения зримости для Гете. Все остальные внешние чувства, внутренние переживания, размышления и абстрактные понятия объединялись вокруг видящего глаза как своего центра, как первой и последней инстанции. Аналогичные моменты прослеживаются и в романе «Преступление и наказание». Смысловыми узлами романа выступает цветовой код, который не только представляет психологическое состояние героев, но и выражает самые сложные и отвлеченные понятия и идеи, которые транслирует писатель с помощью символических моделей. Достоевский, как и Гете, одинаково далек и от примитивного грубого сенсуализма, и от узкого эстетизма (Knapp, 1996). «Bce, что существенно может быть и должно быть зримо, все незримое- несущественное»,- отмечал М. М. Бахтин (Бахтин. Т. 3, 2012: 294). Достоевский-художник призывал себя выражать свое отношение к героям «сценами, а не словами» (Д3о. Т. 16: 301).

Кроме определения герменевтического поля бледного цвета, возможно обозначить бледный цвет в качестве «знака», согласно положениям, разработанным Ч. С. Пирсом. В этом случае слово «знак» будет употребляться для обозначения объекта, доступного восприятию, или только вообразимого, или в определенном смысле даже невообразимого (Пирс, 2000: 178). Знак, таким образом, выступает аналогом не только какого-либо объекта, но и общепринятого представления об этом объекте или совокупности объектов. Кроме того, знак может вообще не иметь предметного аналога, выражая абстрактное понятие или объект, в действительности не существующий. Однако содержание знака не исчерпывается этим: в процессе своего функционирования знак может получать дополнительные значения (коннотации), нередко весьма объемные и отвлеченные, носящие ассоциативный характер и локализующиеся в самых разных социокультурных общностях (этнических, субкультурных, профессиональных и проч.). Помимо предметного и смыслового значения, знак «бледный» имеет также значение экспрессивное, т. е. выражает те или иные чувства, эмоции, настроения 
человека в определенном контексте (Пирс, 2000: 176-234). «Сцены», где упоминается знак «бледный», в этом случае возможно рассматривать как сложные объекты, состоящие из совокупности объектов (там же: 179). Слово «бледный» как знак выражает метафору на базе общих представлений о концепте «бледный», а именно, бледность - это один из отличительных признаков аристократии. Другое значение знака сложнее проанализировать и интерпретировать, потому оно строится не на основе базовых представлений, а в соответствии с ассоциациями автора. Как считает А. П. Шустова,

нельзя точно сказать, что имел в виду автор, можно только предположить, при этом допускаются самые разные толкования, иногда - диаметрально противоположные (Шустова, 2019: 65-70).

При декодировании цветового кода с помощью системы цвета И. В. Гете обращает на себя внимание тот факт, что Гете обозначает на цветовом круге не только цвета, связанные с цельностью, но и другие, расположенные по хордам цветового круга, в частности, бледный, возникающий при смешении желтого и синего цветов, что является самым простым сочетанием.

Можно сказать, что оно чересчур скудно: так как в нем нет и следа красного, то ему слишком далеко до цельности. В этом смысле его можно назвать бледнъм и - поскольку оба полюса стоят на самой низкой ступени - объденным (курсив наш. - Ю.Е.). Зато у него то преимущество, что оно ближе всего стоит к зеленому цвету, а следовательно, к реальному удовлетворению (Гете, Канаев, 1957: 323).

Перевод с немецкого и комментарии подготовлены И. И. Канаевым. Если обратиться к иным версиям перевода, то возможно искажение смысла первоначального текста Гете. Например, перевод с немецкого В. О. Лихтенштадта звучит так (Гете, Лихтенштадт, 2012: 49-50):

Можно сказать, что в нем-всего слишком мало: так как в нем нет ни следа красного, то ему слишком далеко до цельности. В этом смысле можно назвать его бедным и - так как оба полюса стоят на самой низкой ступени - пошлым (курсив наш. - Ю.Е.). Зато у него то преимущество, что он стоит ближе всего к зеленому цвету. Значит, к реальному удовлетворению.

Происходит замена слов «бледный» на «бедный» и «обыденный» на «пошлый». Исходя из смыслового контекста, первый вариант перевода, конечно, более корректен для декодирования цветового кода. 
Ф. М. Достоевский уделяет много внимания внешности главного героя романа Родиона Романовича Раскольникова - бедного студента в возрасте 23 лет: «он был замечательно хорош собою, с прекрасными темными глазами, темно-рус, ростом выше среднего, тонок и строен» (Дзо. Т. 6: 6), «в тонких чертах молодого человека» (там же), «не опуская черных воспаленных глаз своих» (там же: 83), «какая-то дикая энергия заблистала вдруг в его воспаленных глазах и в его исхудалом бледно-желтом лице» (там же: 120), «бледное лицо Раскольникова» (там же: 182). Бледность, мертвенная бледность лица, несколько раз подчеркиваемая писателем, сохраняет трагическую цельность данного образа. Внешность Раскольникова - это внешность аристократа, который создан совсем не для той жизни, которую он вынужден вести.

В романе различные упоминания бледности встречаются около 80 раз. Герменевтическое поле бледного цвета включает первичный (буквальный) смысл, когда этот цвет интерпретируется как состояние кожи лица «без румянца, лишенной естественной окраски». Бледный как самостоятельный цвет не рассматривался ранее в творчестве Достоевского. В тексте романа в значении степени бледности или насыщенности имя прилагательное «бледный» используется в словосочетаниях «бледножелтый», «бледно-зеленый», «бесцветно-бледным». «Бледный», т. е. лишенный естественной окраски, может использоваться в значении «светлый, негустой, неяркий, избела, белесоватый; о светящемся теле: неяркий, несветлый, тускловатый» (Даль, 1998: 245). Степень яркости тоже можно определить словом «бледность», но применительно к тексту романа слово «яркость» используется в смысле психологического воздействия на читателя. Бледность у главных персонажей появляется не от случая к случаю, она присутствует всегда. В наиболее важных сценах романа, когда герою необходимо принять для себя то или иное решение, $\Phi$. М. Достоевский опять же обращается к бледному цвету. Последний предсмертный вопрос Алены Ивановны прозвучал так: «Да чтой-то вы какой бледный?..» Свое признание в убийстве Раскольников совершает «с побледневшими губами». В сцене признания Соне в совершенном преступлении Раскольников «бледно улыбается», затем «вдруг бледнеет», а потом становится «мертвенно-бледным» и т. д. Соня в этой сцене также «становилась все бледнее и бледнее». Как отмечает А. Н. Исаков,

в данном небольшом эпизоде имеет место очевидный перебор бледности, явно нарушающий стилистическую норму, однако текст в указанном фрагменте не производит впечатления ущербности, скорее, наоборот, это одна из наиболее 
сильных по внутренней экспрессии сцен романа. Остается только понять природу этой экспрессивности (Исаков, 2015: 33-34).

По справедливому замечанию М. Пастуро,

цвет не может «найти себя» самостоятельно. Он может обрести смысл и начать полноценно «работать», только когда его ассоциируют с другими цветами или противопоставляют им (Пастуро, Кулиш, 2017: 10).

В связи с этим целесообразно проанализировать бледный цвет во взаимосвязи с синим / голубым и желтым, которые, по мнению Гете, выступают основой бледного, служат для выявления вторичного (иносказательного) смысла бледного цвета. Помимо бледного цвета кожных покровов, еще одной особенностью аристократической внешности является «голубая кровь». Эта метафора, такая же как «белая кость», говорит об отличии представителей высшего сословия от простолюдинов. Катерина Ивановна из самого благородного,

можно сказать, аристократического дома, полковничья дочь и уж, наверное, получше иных искательниц приключений, которых так много расплодилось в последнее время (Дзо. Т. 6: 298).

В общественном сознании произошла стереотипизация, когда аристократов называли людьми голубых кровей, так как поверхностные кровеносные сосуды казались голубыми через бледную кожу. Непривилегированное сословие состояло в основном из бывших крестьян, проводивших большую часть времени на открытом воздухе. Из-за частого пребывания под солнцем их кожа была загорелой, смуглой. Стереотип аристократичной внешности прослеживается и в других литературных произведениях периода создания романа «Преступление и наказание». Например, в романе Н. С. Лескова «Обойденные» (1865) внешность Кирилла Онучина описывается так (Лесков, 1998: 156):

По происхождению, состоянию, а равно по тонкости и белизне кожи, сквозь которую видно было, как благородная кровь переливается в тоненьких, голубых жилках его висков, Кирилл Онучин был аристократ, но ни одного аристократического стремления, ни одного исключительного порока и недостатка, свойственного большинству наших русских патрициев, в Кирилле Онучине не было и запаха, и тени.

Как верно отметил Ю. М. Лотман, «у Достоевского идеологический замысел иллюстрируется реальностью» (Лотман, 2012: 99). Ф М. Достоевский охарактеризовал бледным цветом персонажей, принадлежащих к дворянскому сословию - аристократам: Родиона Раскольникова, 
Соню Мармеладову, Дуню Раскольникову, Лужина, Екатерину Ивановну, Свидригайлова и т. д. Обедневшие, опустившиеся на самое дно и зажиточные представители этого сословия, показанные в романе «Преступление и наказание», живут или пытаются выжить в эпоху реформ императора Александра II. В этот период русское дворянство постепенно, с начала правления отца Александра II-императора Николая I, продолжает приходить в упадок. Дело декабристов оказало сильнейшее влияние на Николая І. Был сделал вывод о неблагонадежном настроении всего дворянства. Николай І постарался создать вокруг себя бюрократию и править страной посредством послушных чиновников. В свою очередь дворянство было запугано делом декабристов и само устранялось от общественной деятельности.

Учитывая, что для появления бледного цвета необходимы синий / голубой и желтый в произвольных пропорциях, можно говорить о слабой интенсивности синего / голубого и сильной насыщенности желтого. В контексте настоящей статьи важно рассмотреть только то коннотативное значение желтого, которое необходимо для декодирования бледного цвета. В романе «Преступление и наказание» достаточно аллегорий, к одной из них можно отнести обозначение желтым цветом негативных явлений в обществе, происходящих в результате непродуманного проведения либеральных реформ. Ф. М. Достоевский не первый обозначил либерализм желтым цветом. Особенно близким для Достоевского было философское обоснование понятия свободы, о котором так много говорилось в либеральной прессе. Достоевский писал в «Дневнике» (Д15. Т. 14: $\left.7^{-}-71\right)$ :

В нынешнем образе мира полагают свободу в разнузданности, тогда как настоящая свобода - лишь в одолении себя и воли своей, так, чтобы под конец достигнутого такого нравственного состояния, чтобы всегда во всякий момент быть самому себе настоящим хозяином. А разнузданность желаний ведет лишь к рабству вашему... Вот почему чуть-чуть не весь нынешний мир полагает свободу в денежном обеспечении и в законах, гарантирующих денежное обеспечение... А между тем это в сущности не свобода, а опятьтаки рабство, рабство от денег.

Характеризуя главные черты русского либерализма, Ф. М. Достоевский писал, что это «страшное презрение к народу... Русскому народу ни за что в мире не простят желание быть самим собой... Все черты народа осмеяны и преданы позору». Либералов он оценивал следующим образом: «Наши либералы-самые отсталые ретрограды...» (Д15. Т. 7: 7) 
Следует отметить, что уже после смерти писателя о желтом цвете вновь заговорили как о символе либерализма. Это произошло в 1928 г. в Великобритании, когда лидер Либеральной партии канцлер казначейства Дэвид Ллойд Джордж опубликовал отчет о партийном расследовании «Промышленное будущее Великобритании». Отчет назвали «желтой книгой», поскольку со второй половины ХIX в. сенсационные, фантастические и приключенческие рассказы публиковались в периодических изданиях с желтыми обложками. С этого времени желтый цвет вновь стал указывать на свободу, развитие и новизну и был принят в качестве логотипа Либеральной партии. С 1988 г. желтый цвет- официальный цвет партийной символики британских либерал-демократов. Применительно к американскому опыту возможно привести ассоциацию с желтым Д. Джармена (Джармен, Андронов, 2017: 102):

Прошла сотня лет с тех пор, как в Нью-Йорке изобрели желтую прессу; подстрекающая к войне и разжигающая ксенофобию, она вытягивает желтые монетки из ваших карманов. Она наставляет культуре рога. Бредовая, предательская, свихнувшаяся.

Для того чтобы было возможно определить особенности конституирования смысла литературного произведения, требуется изучить и реконструировать исторические условия его создания для релевантного его восприятия и интерпретации. Для уяснения смысла декодирования бледного цвета в романе следует охарактеризовать общественные условия, которые предшествовали его написанию. Так, 19 февраля 1855 г. на российский престол взошел император Александр ІІ. Его называли царем-освободителем, поскольку он отменил в 1861 г. крепостное право, провел военную, судебную (введена трехуровневая судебная система, включающая мировой суд, окружной суд и Сенат-высшую судебную инстанцию) и земскую реформы (органом местного самоуправления стали земства). 3 декабря 1855 г. был закрыт особый Комитет по делам печати, созданный в 1849 г. для высшего надзора за цензурой и печатью и преследовавший даже прошедшие обычную цензуру публикации, которые заключали в себе хотя бы малейший намек на свободомыслие. Еще ничего не было формально разрешено, но уже многое не запрещалось или фактически не преследовалось (Трагедия реформатора, 1979: 11). Нельзя оставить без внимания и тот факт, что после каторги $\Phi$. М. Достоевский не мог открыто излагать свои мысли относительно ситуации в России, что было связано с его тяжелым опытом ссылки (Климова, 2018; Сараскина, 2013). Писатель был крайне осторожен 
при словесном формулировании своих идей, он их кодировал, выражал в символической форме в литературных произведениях. Из показаний Ф. М. Достоевского (Д15. Т. 12: 223):

Я говорил об цензуре, об ее непомерной строгости в наше время и сетовал об этом; ибо чувствовал, что произошло какое-то недоразумение, из которого и вытекает натянутый, тяжелый для литературы порядок вещей. Мне грустно было, что звание писателя унижено в наше время каким-то темным подозрением и что на писателя, уже заранее, прежде чем он написал что-нибудь, цензура смотрит как будто на какого-то естественного врага правительству и принимается разбирать его рукопись уже с очевидным предубеждением.

Ф. М. Достоевский показал произошедший в обществе раскол (еще один смысл фамилии героя романа-Раскольникова), не столько межклассовый, сколько внутрисословный, и зарождение нового, в будущем правящего слоя - интеллигенции. Он также продемонстрировал пагубность влияния европейских либеральных реформ на развитие российского общества, ибо Россия должна идти по пути эволюции, а не революции, так как это наиболее правильный путь для великой страны.

Для Достоевского государственно-правовые реформы, описанные в романе, не просто фон, а некий каркас всего произведения. Судебная реформа 1864 г. ознаменовала собой сдвиг в российской правовой культуре от аморфной, коррумпированной системы процедур, структуры и обычного права к независимой и вестернизированной системе, столь же либеральной, как любая нация Европы. Эта реформа была почти повсеместно воспета юридическими и культурными критиками как в то время, когда она была введена, так и в исторических отчетах. Несмотря на очевидную необходимость введения новой судебной системы и успех новых судов, Ф. М. Достоевский постоянно критиковал их в своих художественных и публицистических произведениях. Например, в романе «Преступление и наказание» Ф. М. Достоевский пишет: «...все эти наши новости, реформы, идеи - все это и до нас прикоснулось в провинции; но чтобы видеть яснее и видеть все, надобно быть в Петербурге» (Д3о. Т. 6: 115). Или (там же: 258):

...и все-то одно и то же, все-то одно и то же, как барабан! Вон реформа идет, и мы хоть в названии-то будем переименованы, хе-хе-хе! А уж про приемы-то наши юридические-как остроумно изволили выразиться - так уж совершенно вполне с вами согласен-с. Ну кто же, скажите, из всех подсудимых, даже из самого посконного мужичья, не знает, что его, например, сначала начнут 
посторонними вопросами усыплять (по счастливому выражению вашему), а потом вдруг и огорошат в самое темя...

В записной тетради 1864-1865 гг. Ф. М. Достоевский отмечает (Розенблюм, Полонская, Борщевский, 1971: 219):

...отнюдь не надо ждать, пока у нас образуются адвокаты, т. е. пока мы подрастем да разовьемся, а лучше уже вводить суды повсеместно, без дожидания. Во всяком случае хуже прежних судов не будет, хотя бы новые поступили большею частию или старье или [повсе] неумелая молодежь. В этом решении надобно различать главнейшую идею: именно что подготовка никогда не делается предварительно: будут только болтать, будет только одна болтовня и ничего больше. На деле, на деле совершится подготовка!

По мнению Ф. М. Достоевского, даже если сначала пойдет плохо, все равно будет лучше прежних судов. Подготовка должна выражаться в деле, а не разговорах: «Дело очищает разум, формирует человека, а болтовня растлевает» (там же). Справедлива и актуальна мысль писателя о том, что если только готовиться да готовиться, то только укоренится еще большая болтовня и уже окончательно искоренится всякая выдержка в молодых людях.

Героем романа, молодым человеком из семьи аристократов, формулируется идея элитарности (избранности), презрения к основной части человечества. Достоевский показывает один из этапов рождения русской интеллигенции, которая в последующем боролась за духовную власть с аристократией. Пыталась подражать ей, и неистово завидовала, и ненавидела ее за служение «Царю и Отечеству». Ф. М. Достоевский особо отмечает, что такие понятия, как «долг» и «честь», отсутствие компромиссов с совестью не свойственны для зарождающейся элиты. Наоборот, компромисс для интеллигента - привычная тактика выживания. Русский христианский мыслитель, историк церковной культуры и публицист Г. П. Федотов писал, что русская интеллигенция «идейна» и «беспочвенна» (Федотов, 1927: 145-184). Двигателем всех трех русских революций была именно интеллигенция.

Таким образом, художественный метод писателя предполагает творческое взаимодействие с читателем, который мыслит, интерпретирует, стараясь использовать разные, часто диаметрально противоположные точки зрения, предложенные в метатексте романа. Государственноправовые реформы, отраженные в романе, представляют собой концептуальный каркас, который позволяет сохранить связь вымышленного 
и реального мира. Под воздействием личных переживаний и памяти Достоевский, кодируя информацию с помощью бледного цвета, увеличивал коммуникативную дистанцию с создаваемыми литературными героями. Именно через цветовой код в романе «Преступление и наказание» $Ф$. М. Достоевский выразил свое отношение к государственно-правовой реальности, в которой он жил.

Герменевтическое поле бледного цвета включает первичный смысл, а именно психологические характеристики, выражающие эмоциональное состояние героев. Вторичный (иносказательный) смысл заключается в указании на внутрисословный раскол общества и зарождение нового, в будущем правящего слоя - интеллигенции. В произведении герменевтическое поле синего/голубого цвета в связи с бледным цветом имеет ассоциацию с принадлежностью к аристократии («голубая кровь»). $\mathrm{C}$ помощью символического способа определяется вторичный смысл желтого цвета: государственные реформы, либерализм (свобода). Достоевский показал пагубность влияния европейских либеральных реформ на развитие российского общества.

Вовлекаясь в разные смысловые уровни интерпретации, цветовые коды не конкурируют между собой и не дублируют друг друга, но используются совместно как комплекс средств формирования и осмысления семиотизируемого с их помощью пространства романа. Смыслы цветового кода продолжают жить за пределами своего исторического периода как признанные семиотические ресурсы, которые могут быть использованы для интерпретации идей Достоевского.

\section{СОКРАШЕНИЯ}

Д15 Достоевский Ф. М. Полное собрание сочинений : в 15 т. / под ред. В.Н. Захарова. - М., Л. : Наука, 1988-1996.

Т. 7 : Бесы / под ред. В. А. Туниманова. - 1990.

Т. 12 : Дневник писателя, 1873 . Статьи и очерки, 1873-1878 / под ред. А. В. Архиповой, Г. Я. Галагана. - 1994.

Т. 14 : Дневник писателя, 1877,1880 , август 1881 / под ред. Н. Ф. Будановой, В. А. Туниманова. - 1995.

Дзо Достоевский Ф. М. Полное собрание сочинений : в 30 т. / под ред. В. Г. Базанова, Г. М. Фридлендера, В. В. Виноградова. - М., Л. : Наука, 1972-1990.

Т. 6 : Преступление и наказание : роман в 6 ч. с эпилогом / под ред. Л. Д. Опульской. - 1973.

Т. 16 : Подросток / под ред. В. Г. Базанова, А. В. Архиповой. - 1976. 


\section{ЛИТЕРATУРA}

Бахтин М. М. Проблемы поэтики Достоевского. - М. : Советская Россия, 1979. Бахтин М. М. Время и пространство в произведениях Гете // Эстетика словесного творчества. - М. : Искусство, 1986. - С. 216-250.

Бахтин М. М. Собрание сочинений. В 7 т. Т. 3 / под ред. С. Г. Бочарова, В. В. Кожинова. - М. : Языки славянских культур, 2012.

Боияновский В. Краски у Достоевского // Жизнь искусства. - 1921. - № 187. C. 3 .

Гете И. В. Избранные сочинения по естествознанию / под ред. Е. Н. Павловского ; пер. с нем. И. И. Канаева. - М. : Издательство Академии наук СССР, 1957.

Гете И. В. Учение о цвете. Теория познания / пер. с нем. В. О. Лихтенштадта. - М. : Либроком, 2012.

Даль В.И. Толковый словарь живого великорусского языка. В 4 т. Т. 1. М. : Цитадель, 1998.

Джнармен Д. Хрома. Книга о цвете / пер. с англ. А. М. Андронова. - М. : Ад Маргинем Пресс, 2017.

Зильберштейн И. С., Розенблюм Л. М. От редакции // Литературное наследие. 1971. - Т. $83 .-$ C. $5^{-8 .}$

Исаков А.Н. Достоевский и Лакан. Анализ текста «Преступления и наказания» // EINAI : Философия. Религия. Культура. - 2015. - T. 4, № 1/2. - С. 2243.

Каленкова О. Н. Цветовая гамма в «Преступлении и наказании» Ф. М. Достоевского // Русская речь. - 1982. - № 1. - С. 9-12.

Климова C. М. Интеллигенция в поисках идентичности. Достоевский- Толстой. - СПб. : Алетейя, 2018.

Кочетова И. В. Цветовая символика как отражение творческого метода А. Белого и его метаязыкового сознания // Вестник КемГУ. - 2010. - № 2. - С. 103107.

Кравченко З.А. Философские идеи Ф.М. Достоевского в контексте цветовой символики его произведений // Гуманитарное пространство. - 2019. № $7 / 8$. - С. $912-920$.

Кушхова А. Л. Художественная символика цвета в романе Ф. М. Достоевского «Преступление и наказание»// Литературное обозрение : история и современность. - 2011. - № 1. - С. $23^{-27}$.

Лесков Н. С. Собрание сочинений. В 12 т. Т. 3. - М. : Правда, 1998.

Лотман Ю. М. О русской литературе. - СПб. : Искусство, 2012.

Пастуро М. Синий. История цвета / пер. с фр. Н. Кулиш. - М. : Новое литературное обозрение, 2017.

Переверзев В. Ф. Творчество Достоевского. - М. : Современные проблемы, 1912.

Рикёр П. Конфликт интерпретаций : очерки о герменевтике / пер. с фр., под ред. И. С. Вдовиной. - М. : Академический проект, 2008. 
Розенблюм Л. М., Полонская К., Борщевский С. С. Записная тетрадь (1864-1865) // Литературное наследство. - 1971. - Т. 83. - С. 201-242.

Сараскина Л. И. Достоевский. - М. : Молодая гвардия, 2013.

Соловъев C. М. Изобразительные средства в творчестве Ф. М. Достоевского. М. : Советский писатель, 1979.

Трагедия реформатора : Александр ІІ в воспоминаниях современников / под ред. Б. Маловидова. - СПб. : Д. А.Р. К., 1979.

Федотов Г. П. Трагедия интеллигенции // Версты. - 1927. - Т. 2. - С. $145^{-184}$. Шустова А. П. Спектр значений и ассоциаций лексемы «белый» в русском языке и в текстах разного рода : универсальное и специфическое // Вестник Курганского государственного университета. - 2019. - Т. 52, № 1. - С. $65^{-} 7^{0 .}$ Erokhina $Y$. Semiotic Interpretation of the Sign "Ecclesiastical Court" Within the Framework of Legal Precepts in Terms of Temporality and Spatiality (Case of Russia) // International Journal for the Semiotics of Law. - 2021a. - Vol. 34. - P. $783^{-}$ 802 .

Erokhina $Y$. The Color Code of National Identity in Fyodor Dostoyevsky's Novel Crime and Punishment : Semiotic and Legal Analysis // International Journal for the Semiotics of Law. - 2021b. - Vol. 33. - P. 1-26.

Hardin C.L. Colour for Philosophers : Unweaving the Rainbow. - Indianapolis : Hackett, 1988.

Knapp L. The Annihilation of Inertia. Dostoevsky and Metaphysics : Unweaving the Rainbow. - Evanston : Northwestern University Press, 1996.

Kress G. Colour as a Semiotic Mode : Notes for a Grammar of Colour Institute of Education // Visual Communication. - 2002. - No. 1. - P. $343^{-} 3^{68}$.

Masaryk T. G. Studie o F. M. Dostojevskem (s rukopisnymi poznamkami). - Praha : Slovansky ustav a Spolechost Dostoevskeho, $193^{2}$.

Matl J. Goethe bei den Slaven // Jahrbücher für Kultur und Geschichte der Slaven. 1932. - Nr. 8. - S. $37^{-} 57$.

Ricoeur P. Interpretation Theory : Discourse and the Surplus of Meaning. - Fort Worth : Texas Christian University Press, 1976. 
Yerokhina, Yu. V. 2021. "Tsvetovoye konstruirovaniye deystvitel'nosti v romane Dostoyevskogo 'Prestupleniye i nakazaniye' [Color Construction of Reality in the Novel 'Crime and Punishment' by Dostoevsky]: semantika blednogo tsveta [Semantics of Pale Colour]" [in Russian]. Filosofiya. Zhurnal Vysshey shkoly ekonomiki [Philosophy. Journal of the Higher School of Economics] 5 (3), 140-158.

YULIYA YEROKHINA

PhD in LaW, Associate Professor

HSE UNIVERSity (MOSCOW, RUSSIA); ORCID: 0000-0001-7004-4808

\section{Color Construction of Reality in the Novel "Crime AND PUNishMENT" BY DOSTOEVSKY Semantics of Pale Colour}

Submitted: July 15, 2021. Reviewed: July 30, 2021. Accepted: Aug. 13, 2021. Abstract: The article attempts to model an image of what could be the world of pale colour in the novel "Crime and Punishment" by F.M. Dostoevsky including all constituents such as lexis, title and meaning of colour, codes underlying them (cultural, state, social, etc.), normative legal acts of that time, state legal ideas. The article pays attention to pale colour: its hermeneutical field is defined, primary (literal) and secondary (allegoric) meanings are identified. The key to decoding of colour code in the novel "Crime and Punishment" by F. M. Dostoevsky is tractate "Theory of Colours" by J.W. Goethe, particularly, the linkage between pale and yellow and blue/dark blue colours is traced, the low intensity of blue/dark blue and the distinctive saturation of yellow is indicated. It is concluded that there is an opportunity to consider pale colour as a sign in the analysis of separate scenes in the novel. Both methodological and gnoseological difficulties when decoding and interpreting pale colour in the lexico-semantic field of the novel are highlighted. Attention is drawn to the need of study and reconstruction concerning historical conditions of a literary work creation in order to determine the features of the constituting of its meaning, for the relevant perception and interpretation of pale colour.

Keywords: Pale Colour, F. M. Dostoevsky, Colour Code, Hermeneutical Field, State Legal Reforms, Aristocracy, Intelligentsia, Semantics.

DOI: $10.17323 / 2587-8719-2021-3-140-158$.

\section{REFERENCES}

Bakhtin, M. M. 1979. Problemy poetiki Dostoyevskogo [Problems of Dostoevsky's Poetics] [in Russian]. Moskva [Moscow]: Sovet-skaya Rossiya.

. 1986. "Vremya i prostranstvo v proizvedeniyakh Gete [Time and Space in the Works of Goethe]" [in Russian]. In Estetika slovesnogo tvorchestva [Aesthetics of Verbal Creativity], 216-250. Moskva [Moscow]: Iskusstvo.

- 2012. [in Russian]. Vol. 3 of Sobraniye sochineniy [Collected Works], ed. by S. G. Bocharov and V. V. Kozhinov. 7 vols. Moskva [Moscow]: Yazyki slavyanskikh kul'tur.

Botsyanovskiy, Vl. 1921. "Kraski u Dostoyevskogo [Dostoevsky's Paints]" [in Russian]. Zhizn' iskusstva [Life of Art], no. 187: 3.

Dal', V. I. 1998. [in Russian]. Vol. 1 of Tolkovyy slovar' zhivogo velikorusskogo yazyka [Explanatory Dictionary of the Living Great Russian Language]. 4 vols. Moskva [Moscow]: Tsitadel'. 
Dostoyevskiy, F. M. 1988-1996. Polnoye sobraniye sochineniy [Complete Works] [in Russian]. Ed. by V. N. Zakharov. 15 vols. Moskva [Moscow] and Leningrad: Nauka.

Erokhina, Yu. 2021a. "." International Journal for the Semiotics of Law 34:783-802. . 2021b. "The Color Code of National Identity in Fyodor Dostoyevsky's Novel Crime and Punishment: Semiotic and Legal Analysis." International Journal for the Semiotics of Law 33:1-26.

Fedotov, G. P. 1927. "Tragediya intelligentsii [The Tragedy of the Intelligentsia]" [in Russian]. Versty [Versts] 2:145-184.

Goethe, J.W. 1957. Izbrannyye sochineniya po yestestvoznaniyu [Selected Works on Natural Science] [in Russian]. Ed. by Ye. N. Pavlovskiy. Trans. from the German by I.I. Kanayev. Moskva [Moscow]: Izdatel'stvo Akademii nauk SSSR.

- 2012. Ucheniye o tsvete. Teoriya poznaniya [Teaching about Color. Theory of Knowledge] [in Russian]. Trans. from the German by V. O. Likhtenshtadt. Moskva [Moscow]: Librokom.

Hardin, C. L. 1988. Colour for Philosophers: Unweaving the Rainbow. Indianapolis: Hackett.

Isakov, A. N. 2015. "Dostoyevskiy i Lakan. Analiz teksta 'Prestupleniya i nakazaniya' [Dostoevsky and Lacan. Analysis of the Text of 'Crime and Punishment']" [in Russian]. EINAI [EINAI]: Filosofiya. Religiya. Kul'tura [Philosophy. Religion. Culture] 4 (1/2): 22-43.

Jarman, D. 2017. Khroma. Kniga o tsvete [Chroma] [in Russian]. Trans. from the English by A. M. Andronov. Moskva [Moscow]: Ad Marginem Press.

Kalenkova, O. N. 1982. "Tsvetovaya gamma v 'Prestuplenii i nakazanii' F. M. Dostoyevskogo [Color Scale in 'Crime and Punishment' by F.M. Dostoevsky]" [in Russian]. Russkaya rech' [Russian Speech], no. 1: 9-12.

Klimova, S. M. 2018. Intelligentsiya v poiskakh identichnosti. Dostoyevskiy - Tolstoy [Intelligentsia in Search of Identity. Dostoevsky - Tolstoy] [in Russian]. Sankt-Peterburg [Saint Petersburg]: Aleteyya.

Knapp, L. 1996. The Annihilation of Inertia. Dostoevsky and Metaphysics: Unweaving the Rainbow. Evanston: Northwestern University Press.

Kochetova, I. V. 2010. "Tsvetovaya simvolika kak otrazheniye tvorcheskogo metoda A. Belogo i yego metayazykovogo soznaniya [Color Symbolism as a Reflection of A. Bely's Creative Method and His Metalanguage Consciousness]" [in Russian]. Vestnik KemGU [Bulletin of the KemSU], no. 2: 103-107.

Kravchenko, Z. A. 2019. "Filosofskiye idei F. M. Dostoyevskogo v kontekste tsvetovoy simvoliki yego proizvedeniy [Philosophical Ideas of F. M. Dostoevsky in the Context of the Color Symbolism of His Works]" [in Russian]. Gumanitarnoye prostranstvo [Humanitarian Space], nos. 7/8: 912-920.

Kress, G. 2002. "Colour as a Semiotic Mode: Notes for a Grammar of Colour Institute of Education." Visual Communication, no. 1: 343-368.

Kushkhova, A. L. 2011. "Khudozhestvennaya simvolika tsveta v romane F. M. Dostoyevskogo 'Prestupleniye i nakazaniye' [Artistic Symbolism of Color in the Novel by F. M. Dostoevsky 'Crime and Punishment']" [in Russian]. Literaturnoye obozreniye [Literary Review]: istoriya $i$ souremennost' [History and Modernity], no. 1: 23-27.

Leskov, N. S. 1998. [in Russian]. Vol. 3 of Sobraniye sochineniy [Collected Works]. 12 vols. Moskva [Moscow]: Pravda.

Lotman, Yu. M. 2012. O russkoy literature [About Russian Literature] [in Russian]. SanktPeterburg [Saint Petersburg]: Iskusstvo. 
Malovidov, B., ed. 1979. Tragediya reformatora [The Tragedy of the Reformer]: Aleksandr II v vospominaniyakh sovremennikov [Alexander II in the Memoirs of His Contemporaries] [in Russian]. Sankt-Peterburg [Saint Petersburg]: D. A. R. K.

Masaryk, T. G. 1932. Studie o F. M. Dostojevskem (s rukopisnymi poznamkami) [in Czech]. Praha: Slovansky ustav a Spolechost Dostoevskeho.

Matl, J. 1932. "Goethe bei den Slaven" [in German]. Jahrbücher für Kultur und Geschichte der Slaven, no. 8: 37-57.

Pastoureau, M. 2017. Siniy. Istoriya tsveta [Bleu histoire d'une couleur] [in Russian]. Trans. from the French by N. Kulish. Moskva [Moscow]: Novoye literaturnoye obozreniye.

Pereverzev, V.F. 1912. Tvorchestvo Dostoyevskogo [Creativity of Dostoevsky] [in Russian]. Moskva [Moscow]: Sovremennyye problemy.

Ricoeur, P. 1976. Interpretation Theory: Discourse and the Surplus of Meaning. Fort Worth: Texas Christian University Press.

Ricœur, P. 2008. Konflikt interpretatsiy [Le conflit des interprétations]: ocherki o germenevtike [Essais d'herméneutique] [in Russian]. Ed. and trans. from the French by I.S. Vdovina. Moskva [Moscow]: Akademicheskiy proyekt.

Rozenblyum, L. M., K.A. Polonskaya, and S. S. Borshchevskiy. 1971. 'Zapisnaya tetrad' (18641865) [Notebook (1864-1865)]" [in Russian]. Literaturnoye nasledstvo [Literary Heritage] 83:201-242.

Saraskina, L. I. 2013. Dostoyevskiy [Dostoevsky] [in Russian]. Moskva [Moscow]: Molodaya gvardiya.

Shustova, A.P. 2019. "Spektr znacheniy i assotsiatsiy leksemy 'belyy' v russkom yazyke i v tekstakh raznogo roda [The Spectrum of Meanings and Associations of the Lexeme 'White' in Russian and in Texts of Various Kinds]: universal'noye i spetsificheskoye [Universal and Specific]" [in Russian]. Vestnik Kurganskogo gosudarstvennogo universiteta [Bulletin of the Kurgan State University] 52 (1): 65-70.

Solov'yev, S. M. 1979. Izobrazitel'nyye sredstva v tvorchestve F. M. Dostoyevskogo [Graphic Means in the Works of F.M. Dostoevsky] [in Russian]. Moskva [Moscow]: Sovet.skiy pisatel'.

Zil'bershteyn, I. S., and L. M. Rozenblyum. 1971. "Ot redaktsii [From the Editor]" [in Russian]. Literaturnoye naslediye [Literary Heritage] 83:5-8. 